\title{
Treatment of Cluster Headache in Pregnancy and Lactation
}

\author{
Anne H. Calhoun \\ Department of Psychiatry, University of North Carolina, and the Carolina Headache Institute, 103 \\ Market Street, Chapel Hill, NC 27516, USA \\ B. Lee Peterlin \\ Department of Neurology, Pharmacology \& Physiology, Drexel University College of Medicine, \\ 245 North 15th Street, Philadelphia, PA 19102, USA Lee.peterlin@drexelmed.edu
}

\begin{abstract}
Cluster headache $(\mathrm{CH})$ is a neurovascular headache syndrome characterized by headache attacks that occur with a circadian and circannual periodicity. The calculated prevalence of $\mathrm{CH}$ in reproductive-aged women is 7.5 of 100,000 women. Although data suggest that $\mathrm{CH}$ during pregnancy is a relatively rare condition, when it does occur, attacks remain unchanged in character and severity in the majority of patients. Thus, treatment of $\mathrm{CH}$ in pregnant and lactating women may remain a significant therapeutic challenge. This manuscript briefly reviews the epidemiology of $\mathrm{CH}$ in women, and then focuses on treatment options for both acute and preventative management of $\mathrm{CH}$ in pregnant and lactating women.
\end{abstract}

\section{Keywords}

Cluster headache; Cluster headache treatment; Pregnancy; Lactation

\section{Introduction}

Cluster headache $(\mathrm{CH})$ is a neurovascular headache syndrome characterized by headache attacks that occur with a circadian and circannual periodicity. Typical attacks are unilateral in location, of extreme intensity but short duration, and associated with autonomic dysfunction [1].

There is a relative paucity of information pertaining to $\mathrm{CH}$ in pregnancy and lactation, largely not without cause. $\mathrm{CH}$ is a relatively rare, primary headache disorder that affects an estimated $0.06 \%$ of the population, with an overall male:female ratio of approximately $2.5: 1$ $[1,2]$. However, during reproductive years, the male preponderance is roughly 7:1 [2]. Thus, in reproductive-aged women, this results in a calculated prevalence of $\mathrm{CH}$ of only 7.5 of 100,000 women. To further reduce the population of interest, there are reports of relative hypo-fertility in women with $\mathrm{CH}[3,4]$. Specifically, when onset of attacks preceded a first pregnancy, women had significantly $(P<0.01)$ fewer children than those who were parous before their first attack [5].

Nevertheless, the strong male preponderance in $\mathrm{CH}$ has seen progressive decreases over recent decades, and varies in relationship to age of onset. The decline in the male:female ratio has been attributed to an increase in the number of female sufferers, an increase that

(C) Springer Science+Business Media, LLC 2010

calhouna@carolinaheadacheinstitute.com. 
has paralleled declines in the male:female ratios in smoking and in employment outside the home [6].

In addition, there is also variability in the gender ratio of $\mathrm{CH}$ based on the age of onset. When the onset of $\mathrm{CH}$ is between the ages of 30-49 years (when women are typically premenopausal), the gender ratio for episodic $\mathrm{CH}$ is 7.2:1 and an impressive 11:1 for chronic $\mathrm{CH}$. After the age of 50 years, this gender disparity shrinks to only $2.3: 1$ for episodic $\mathrm{CH}$ cases and disappears altogether (0.6:1) for chronic $\mathrm{CH}$ [2].

Although the relative rarity of these headaches in premenopausal-aged women is suggestive of a possible protective effect of estrogen, the course of $\mathrm{CH}$ does not appear to be modified by the hormonal fluctuation of the menstrual cycle [3]. However, it is important to remember that even the lowest estrogen concentrations encountered in a normal menstrual cycle are many times higher than those found in postmenopausal women, when estrogen concentrations are typically lower than those of even age-matched males.

Data are conflicting as to whether $\mathrm{CH}$ improves in pregnancy or remains unchanged, with most studies limited by small numbers and retrospective design. To illustrate the issue, one review examined 249 patients with $\mathrm{CH}$ [4]. Only 34 patients were female, of whom only eight had experienced pregnancy since the onset of $\mathrm{CH}$; six of those eight reported remission of cluster in the (very) high estrogen environment of pregnancy. In another study of 143 women with $\mathrm{CH}, 111$ had been pregnant; only 19 of these patients reported $\mathrm{CH}$ attacks during a pregnancy, with the majority reporting no increase in severity or frequency of those attacks compared with attacks outside of pregnancy [5]. Another study found that only 5\% of women with $\mathrm{CH}$ experienced attacks during pregnancy [1]. However, it is of note that pregnancy was associated with a change in the women's seasonal pattern of attacks, such that expected seasonal clusters did not occur when pregnant. Taken together, all of these studies suggest that $\mathrm{CH}$ during pregnancy is a relatively rare condition, but when it does occur, attacks remain unchanged in character and severity.

\section{Nonpharmacologic Approaches}

Nonpharmacologic approaches should always be considered first-line therapy, a practice that is particularly important in pregnancy and lactation. Specifically, pregnant women should be strongly encouraged to stop both smoking and excessive alcohol ingestion for a multitude of medical reasons, including potential injury to the fetus, but also because $\mathrm{CH}$ has been shown to have a close association with both smoking and alcohol ingestion [7].

Another nonpharmacological consideration for management of $\mathrm{CH}$ during pregnancy and lactation is screening for sleep apnea. Sleep apnea prevalence has been reported as high as $80 \%$ in patients with episodic $\mathrm{CH}$ attacks [7, 8]. Reports have also suggested that obstructive sleep apnea (OSA) may be more common in pregnancy, particularly in the third trimester; it also may be associated with preeclampsia and harm to the fetus [8]. A reasonable approach would be to ask all cluster patients to complete a screener for OSA, such as the Berlin Questionnaire or the Pittsburgh Sleep Quality Index (See Appendix 1, 2 and 3), with referral for formal evaluation and treatment by a sleep specialist for those who screen positively or whose attacks worsen, especially in pregnancy [9]. Nasal continuous positive airway pressure or an appropriate dental device may then be appropriate considerations in those who do have OSA.

\section{Treatment in Pregnancy}

Many effective treatments exist for both abortive and preventive care of patients with $\mathrm{CH}$. But when the patient is pregnant or lactating, collaboration among the headache specialist, 
obstetrician, and pediatrician is encouraged to ensure safety of both the mother and her developing baby.

Ideally, drugs would not be taken in pregnancy; however, circumstances often favor their judicious use. To illustrate current usage of drugs in pregnancy, a survey of 1,000 pregnant women in southwest France showed that $99 \%$ of the women received a prescription for at least one drug during pregnancy, with a mean of 13.6 medications per woman [10]. Drugs in Category X (fetal risk outweighs benefit) were prescribed to $1.6 \%$ of the women; $59 \%$ had a prescription from Category D (fetal risk exists, but benefits may be acceptable); and 79\% were exposed to drugs for which information about safety in pregnancy was not available from animal or human studies.

The US Food and Drug Administration drug categories in pregnancy are reviewed in Table 1. Category A is almost nonexistent and includes products such as prenatal vitamins and thyroid hormone in physiologic replacement doses. In Categories B and C, harm has not been shown in humans, whereas in Categories $\mathrm{D}$ and $\mathrm{X}$, harm has been shown in humans. In many cases, the difference between Categories B and C may hinge on how high the dose was pushed in laboratory animals.

Beyond these rating categories, treatment decisions may be guided by physiologic studies of drug transport, adverse events reporting, and experience collected from prospective pregnancy registries. In the absence of prospective drug treatment trials in pregnancywhich are rarely if ever conducted - product inserts generally do not recommend use in pregnancy. However, counterbalancing issues of relative safety, it is important to remember that the pain of $\mathrm{CH}$ is excruciating, even to the point of suicide, in patients with intractable or untreated $\mathrm{CH}[11]$.

As with pharmacologic treatment of any medical disorder in pregnancy, a detailed discussion of the risks and benefits of treatment of $\mathrm{CH}$ in pregnancy is essential. In general, the number of different medications as well as their dosage and frequency should be kept to a minimum.

The European Federation of Neurological Societies (EFNS) published evidence-based consensus recommendations for the treatment of $\mathrm{CH}$ in the general (nonpregnant) population [12]. The drugs of first choice were oxygen (100\%, with a flow at least $7 \mathrm{~L} / \mathrm{min}$ over 15 $\mathrm{min}$ ) and sumatriptan (6 $\mathrm{mg}$ subcutaneous). Both of these may also be options in pregnancy for the treatment of $\mathrm{CH}$.

Inhalation of pure oxygen via a non-rebreathing mask is the preferred first-line treatment due to the lack of obvious contraindications to either mother or fetus [13,14]. Delivery of $100 \%$ oxygen during $\mathrm{CH}$ attacks results in cerebral vasoconstriction and stimulates synthesis of serotonin in the central nervous system. A clinical trial of oxygen therapy in $\mathrm{CH}$ found complete resolution of pain within $20 \mathrm{~min}$ in six of the seven oxygen-treated subjects, whereas none of the six control subjects achieved pain resolution. It has also been suggested that higher flow oxygen rates up to $15 \mathrm{~L}$ per minute may be of benefit when lower rates have been unsuccessful [15].

If oxygen treatment is insufficient, injectable or intranasal sumatriptan may be considered. Sumatriptan has been widely used over the past decade and a half in $\mathrm{CH}$. Among several mechanisms of actions, triptans have been shown to bind to serotonin $(5-\mathrm{HT})_{1 \mathrm{~B} / 1 \mathrm{D}}$ receptors and inhibit the release of neuropeptides and inflammatory substrates at the trigeminal vascular junction. In addition, triptans act on central 5- $\mathrm{HT}_{1 \mathrm{D}}$ receptors to limit activation of the trigeminal nucleus caudalis and thus may aid in the prevention of central sensitization. 
Like all triptans, sumatriptan is classified as Category $\mathrm{C}$; however, its safety profile has been documented in pregnancy to a greater extent than other triptans, including exposure in first trimester $[16,17]$. Its relative hydrophilicity makes it more difficult for sumatriptan (compared with more lipophilic triptans) to traverse the placental membrane. In physiologic testing, only about $15 \%$ of a dose crossed into the fetal compartment over $4 \mathrm{~h}$. With an average elimination half-life of $2 \mathrm{~h}$, it is evident that only very small amounts will cross from mother to fetus after a single dose of sumatriptan [18]. Due to significantly lower maternal serum concentration, the nasal spray formulation would be a logical first choice route of administration, with advancement to injection if needed for control of attacks.

Other acute options include intranasal installation of lidocaine (pregnancy Category B), which induces anesthesia in the region of the pterygopalatine fossa and results in rapid relief with a low side-effect profile [12]. Intranasal dihydroergotamine, although effective in the general population of $\mathrm{CH}$ sufferers, would very rarely, if ever, be advocated in pregnancy, as it is Category X. Further, symptomatic treatment with metoclopramide (Category B) or prochlorperazine (Category C) could be employed when necessary.

Thus, in the pregnant patient, oxygen is the most appropriate first-line therapy for acute $\mathrm{CH}$ attacks, with the nasal spray formulation of sumatriptan (Category B) or nasal lidocaine (Category B) as appropriate second-line therapies when required (Table 2).

Both transitional and traditional preventative options may be required for the treatment of $\mathrm{CH}$ in pregnant women. Transitional preventives are those given to break cluster cycles. In this capacity, greater occipital nerve (GON) blockade has demonstrated efficacy in acute $\mathrm{CH}$, and in some cases, will break a cluster cycle. In a small open-label study, 13 of $22 \mathrm{CH}$ patients treated with GON blockade experienced complete or partial response, with partial responses lasting an average of 21 days [19]. Treatment was well tolerated with no adverse events. Although GON blockade has not been specifically tested in pregnancy, it is usually performed with lidocaine and betamethasone, drugs that are rated Categories B and C, respectively (Table 2).

The consensus choice of the EFNS for prevention of $\mathrm{CH}$ in the general (nonpregnant) population was verapamil (Category C) at a daily dose of at least $240 \mathrm{mg}$. In addition to verapamil, steroids are also generally accepted as effective in $\mathrm{CH}$, despite the lack of evidence from class I or class II trials. The recommended dosage of methylprednisone (Category C) is an oral dose of at least $100 \mathrm{mg}$ daily, or an intravenous dosage of up to 500 $\mathrm{mg}$ daily over 5 days before tapering.

Topiramate may be an acceptable alternative to verapamil for $\mathrm{CH}$ prevention in pregnancy. Although not well established (primarily due to small sample sizes and design limitations), several studies have suggested that topiramate may be an effective $\mathrm{CH}$ preventive therapy, with headache remission in $50 \%$ to $70 \%$ of those with episodic or chronic $\mathrm{CH}$. As it is pregnancy Category $\mathrm{C}$, topiramate may be of consideration in pregnant $\mathrm{CH}$ sufferers when prevention is required (Table 2) [20•].

Although methysergide (which is no longer available in the United States and is Category D) and lithium (also Category D) are recommended as alternative treatments in the general population, they are not generally used in pregnancy unless the benefit to the mother "clearly exceeds the risk to the fetus," as harm has been shown in human pregnancies. Finally, surgical procedures for $\mathrm{CH}$ exist, and although promising, require further scientific scrutiny before formal recommendations can be made.

Thus, in the pregnant patient, verapamil (pregnancy Category C) and steroids (Category C) remain the preferred options when preventive treatment is required (Table 2). 


\section{Treatment in Lactation}

Virtually all drugs taken by the mother will be present to some extent in breast milk. Membrane transport is achieved primarily by passive diffusion, with the classic factors of concentration gradient, lipophilicity, protein binding, and degree of ionization determining transport kinetics [21••].

The extent of drug transfer into breast milk is most commonly described quantitatively using the milk:plasma concentration ratio. The infant dose can thus be calculated and expressed as a percentage of the maternal dose. For most drugs, an arbitrary cutoff of $10 \%$ has been accepted as a guide to the safe use of drugs in lactation; however, for drugs with greater inherent toxicity, such as cytotoxic agents, that cutoff would not apply. Rather, breastfeeding would be contraindicated in their presence. Premature infants have a severely limited ability to clear drugs, but, in general, if the infant dose-as a percentage of the maternal dose (corrected for weight) - is close to $1 \%$, the drug can be considered safe regardless of infant age [21••].

The route of administration is also a factor. Topical creams, nasal sprays, or inhalers usually convey less exposure to the breastfed infant than oral drugs due to lower maternal concentrations. Drugs that are poorly absorbed or have high maternal first-pass metabolism are also less likely to be a concern in lactation, along with very hydrophilic drugs that have difficulty crossing physiologic membranes into breast milk. Timing breastfeeding to occur immediately prior to a maternal drug dose may also help to minimize infant exposure, as drug concentrations in milk tend to be lowest at the end of the dosing interval.

The American Academy of Pediatrics (AAP) Committee on Drugs divides medication usage in lactation into seven "tables" (To limit confusion we describe what the AAP terms as "tables" as "categories" of medications in lactation in Table 3.) [22].

The AAP lists sumatriptan as compatible with breastfeeding [22]. Other triptans, many of which are lipophilic, have not yet been reviewed or received this categorization. Also, among compatible medications are lidocaine, prednisone, prednisolone, and verapamil.

Additional points of note include the following: 1) Although the AAP has not issued a position statement for the use of dihydroergotamine in lactation, it considers the use of the related compound ergotamine to be cause for "caution." Ergotamine exposure has resulted in convulsions in the nursing infant. 2) Although metoclopramide is considered relatively safe in pregnancy (Category B) it is of more concern in lactation, where it is concentrated in breast milk relative to the maternal serum concentration, and according to the AAP, "may be of concern." Prochlorperazine, as all phenothiazines, are similarly categorized as "may be of concern" (Table 3). 3) Finally, particular caution should be exercised with lithium, as it crosses readily into breast milk at levels considerably higher than the referenced $10 \%$ cutoff figure-in some cases up to 50\% of the maternal dose [22]. The long-term outcome is unknown, and prescription of lithium to lactating women is controversial [23]. Although there is no absolute contraindication, it is known that the kidney is particularly sensitive to lithium just after birth, and cases of renal toxicity have been reported.

Thus, the preferred agents for acute treatment of $\mathrm{CH}$ during lactation would include oxygen, sumatriptan, and lidocaine; for prevention, prednisone/prednisolone and verapamil would be appropriate first options when required (Table 2) [24]. 


\section{Conclusions}

Cluster headache $(\mathrm{CH})$ is a relatively uncommon neurovascular headache syndrome characterized by headache attacks that occur with a regular periodicity. Although $\mathrm{CH}$ during pregnancy is a relatively rare condition, the data suggest that when it does occur, attacks remain unchanged in character and severity in the majority of patients. Thus, treatment of $\mathrm{CH}$ in pregnant and lactating women may present a significant therapeutic challenge.

Nevertheless, when nonpharmacological agents are not sufficient, it is reassuring that many of our standard first-line therapies for treatment of $\mathrm{CH}$ remain viable options in the pregnant and lactating woman who suffers from these debilitating attacks.

\section{Acknowledgments}

Disclosure Dr. Anne H. Calhoun has received research support from GlaxoSmithKline and Teva; is on the speakers' bureau for GlaxoSmithKline and Merck; and is a consultant for Merck and Teva. Dr. B. Lee Peterlin is a consultant for Ortho-McNeil and Pfizer; is on the speakers' bureau for GlaxoSmithKline, Endo, and Merck; and has received grant support from GlaxoSmithKline. She serves on the editorial board for Headache. She has a patent for the use of adiponectin-modulating drugs for migraine. 


\section{Appendix 1 Berlin questionnaire}

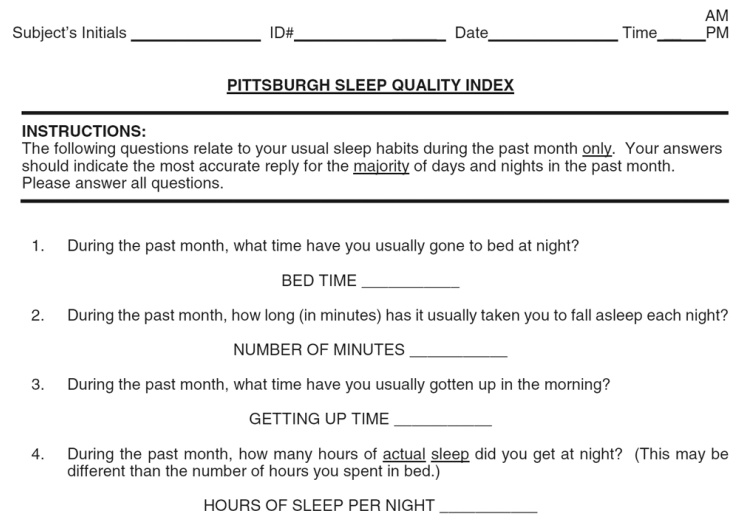


j) Other reason(s), please describe

How often during the past month have you had trouble sleeping because of this?

$\begin{array}{lll}\text { Not during the Less than } & \text { Once or twice } & \text { Three or more } \\ \text { pastmonth } & \text { times a week }\end{array}$

6. During the past month, how would you rate your sleep quality overall?

Very good

Fairly good

Fairly bad

Very bad

7. During the past month, how often have you taken medicine to help you sleep (prescribed or "over the counter")?

$\begin{array}{llll}\begin{array}{l}\text { Not during the } \\ \text { past month }\end{array} & \begin{array}{l}\text { Less than } \\ \text { once a week }\end{array} & \begin{array}{l}\text { Once or twice } \\ \text { a week }\end{array} & \begin{array}{l}\text { Three or more } \\ \text { times a week }\end{array}\end{array}$

8. During the past month, how often have you had trouble staying awake while driving, eating meals, or engaging in social activity?

$\begin{array}{lll}\begin{array}{l}\text { Not during the Less than } \\ \text { pastmonth }\end{array} & \text { Once or twice } & \text { Three or more } \\ \text { a week } & \text { times a week }\end{array}$

9. During the past month, how much of a problem has it been for you to keep up enough enthusiasm to get things done?

No problem at all

Only a very slight problem

Somewhat of a problem

A very big problem

10. Do you have a bed partner or room mate?

No bed partner or room mate

Partner/room mate in other room

Partner in same room, but not same bed

Partner in same bed

If you have a room mate or bed partner, ask him/her how often in the past month you

.

a) Loud snoring

$\begin{array}{llll}\begin{array}{l}\text { Not during the } \\ \text { past month }\end{array} & \begin{array}{l}\text { Less than } \\ \text { once a week }\end{array} & \begin{array}{l}\text { Once or twice } \\ \text { a week }\end{array} & \begin{array}{l}\text { Three or more } \\ \text { times a week }\end{array}\end{array}$

b) Long pauses between breaths while asleep

Not during the Less than Once or twice Three or more

Legs twitching or jerking while you sleep

Not during the Less than Once or twice Three or more

Episodes of disorientation or confusion during sleep

Not during the Less than Once or twice Three or more

past month___ once a week____ a week___ times a week

e) Other restlessness while you sleep; please describe

Not during the Less than Once or twice Three or more

Not during the Less than Once or twice Three or more

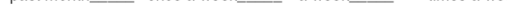




\section{Appendix 2 Pittsburgh sleep quality index}

Pittsburgh Sleep Quality Index (PSQI) References and Scoring

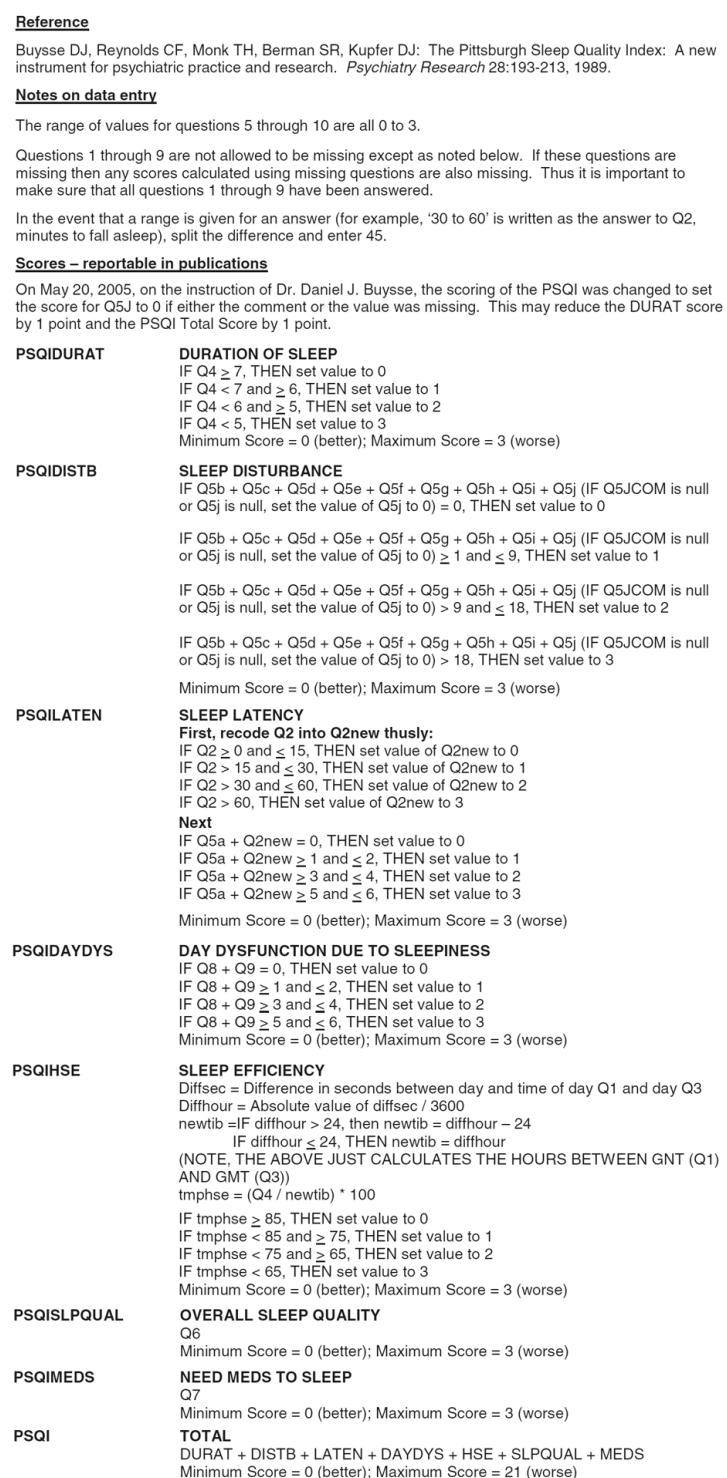




\section{Appendix 3 Pittsburgh sleep quality index references and scoring}

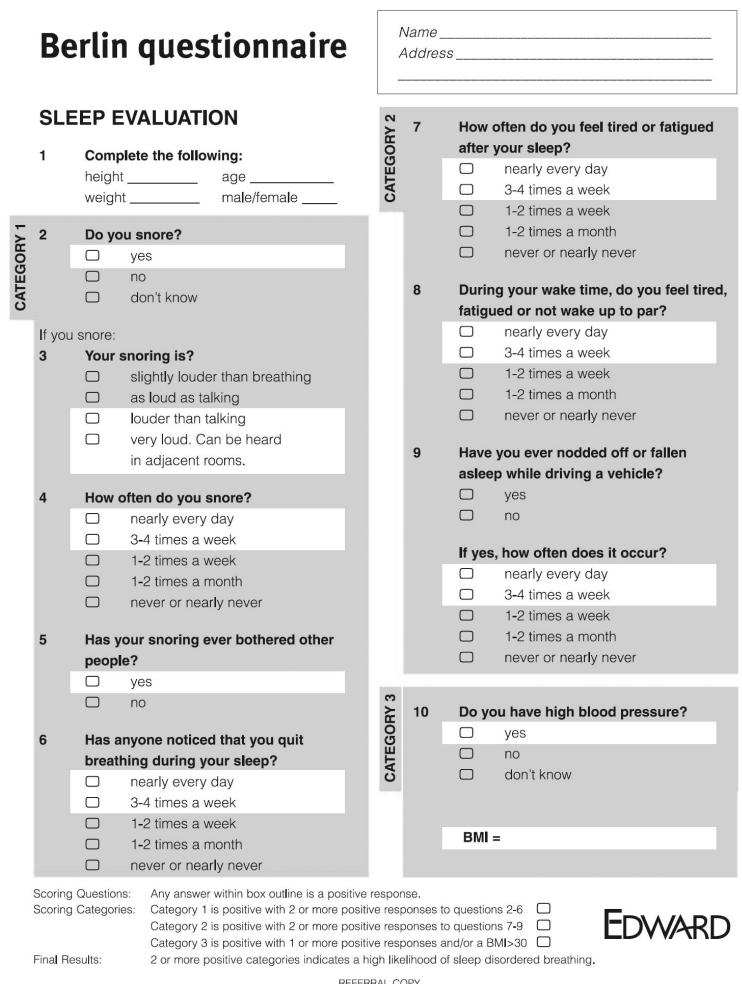

\section{References}

Papers of particular interest, published recently, have been highlighted as:

- Of importance

•• Of major importance

1. Bahra A, May A, Goadsby PJ. Cluster headache: a prospective clinical study with diagnostic implications. Neurology. 2002; 58:354-361. [PubMed: 11839832]

2. Ekbom K, Svensson DA, Traff H, Waldenlind E. Age at onset and sex ratio in cluster headache: observations over three decades. Cephalalgia. 2002; 22:94-100. [PubMed: 11972575]

3. Manzoni GC, Micieli G, Granella F, et al. Cluster headache in women: clinical findings and relationship with reproductive life. Cephalalgia. 1988; 8:37-44. [PubMed: 3359483]

4. Ekbom K, Waldenlind E. Cluster headache in women: evidence of hypofertility(?) Headaches in relation to menstruation and pregnancy. Cephalalgia. 1981; 1:167-174. [PubMed: 7346185]

5. van Vliet JA, Favier I, Helmerhorst FM, et al. Cluster headache in women: relation with menstruation, use of oral contraceptives, pregnancy, and menopause. J Neurol Neurosurg Psychiatry. 2006; 77:690-692. [PubMed: 16407458]

6. Manzoni GC. Gender ratio of cluster headache over the years: a possible role of changes in lifestyle. Cephalalgia. 1998; 18:138-142. [PubMed: 9595206]

7. Graff-Radford SB, Newman A. Obstructive sleep apnea and cluster headache. Headache. 2004; 44:607-610. [PubMed: 15186306]

8. Sahota PK, Jain SS, Dhand R. Sleep disorders in pregnancy. Curr Opin Pulm Med. 2003; 9:477_ 483. [PubMed: 14534398]

9. Netzer NC, Stoohs RA, Netzer CM, et al. Using the Berlin Questionnaire to identify patients at risk for the sleep apnea syndrome. Ann Intern Med. 1999; 131:485-491. [PubMed: 10507956] 
10. Lacroix I, Damase-Michel C, Lapeyre-Mestre M, Montastruc JL. Prescription of drugs during pregnancy in France. Lancet. 2000; 356:1735-1736. [PubMed: 11095263]

11. Rothrock J. Cluster: a potentially lethal headache disorder. Headache. 2006; 46:327. [PubMed: 16492244]

12. May A, Leone M, Afra J, et al. EFNS guidelines on the treatment of cluster headache and other trigeminal-autonomic cephalalgias. Eur J Neurol. 2006; 13:1066-1077. [PubMed: 16987158]

13. Kudrow L. Response of cluster headache attacks to oxygen inhalation. Headache. 1981; 21:1-4. [PubMed: 7007285]

14. Fogan L. Treatment of cluster headache. A double-blind comparison of oxygen $\mathrm{v}$ air inhalation. Arch Neurol. 1985; 42:362-363. [PubMed: 3885921]

15. Rozen TD. High oxygen flow rates for cluster headache. Neurology. 2004; 63:593. [PubMed: 15304611]

16. Loder E. Safety of sumatriptan in pregnancy: a review of the data so far. CNS Drugs. 2003; 17:17. [PubMed: 12467489]

17. Shuhaiber S, Pastuszak A, Schick B, et al. Pregnancy outcome following first trimester exposure to sumatriptan. Neurology. 1998; 51:581-583. [PubMed: 9710039]

18. Schenker S, Yang Y, Perez A, et al. Sumatriptan (Imitrex) transport by the human placenta. Proc Soc Exp Biol Med. 1995; 210:213-220. [PubMed: 8539258]

19. Afridi SK, Shields KG, Bhola R, Goadsby PJ. Greater occipital nerve injection in primary headache syndromes: prolonged effects from a single injection. Pain. 2006; 122:126-129. [PubMed: 16527404]

20•. Pascual J, Lainez MJ, Dodick D, Hering-Hanit R. Antiepileptic drugs for the treatment of chronic and episodic cluster headache: a review. Headache. 2007; 47:81-89. [PubMed: 17355498] This is a good review of three antiepileptic drugs in prevention of $\mathrm{CH}$ : gabapentin, valproic acid, and topiramate. It includes a thorough review of current literature, suggesting topiramate may be a consideration for $\mathrm{CH}$ prevention, and provides recommendations for dose titration.

21••. Ilett KF, Kristensen JH. Drug use and breastfeeding. Expert Opin Drug Saf. 2005; 4:745-768. [PubMed: 16011452] This is an excellent review on the use of pharmacological agents in breastfeeding. It highlights the potential risks to the infant from maternal drug use, the physiology of lactation, the effects of drugs that stimulate or decrease milk production, and factors that may modify the infant's exposure. It covers a variety of drugs, including analgesics and anti-inflammatory agents. This is a must read for anyone treating lactating and breastfeeding women.

22. Ressel G. AAP updates statement for transfer of drugs and other chemicals into breast milk. American Academy of Pediatrics. Am Fam Phys. 2002; 65:979-980.

23. Grandjean EM, Aubry JM. Lithium: updated human knowledge using an evidence-based approach: part III: clinical safety. CNS Drugs. 2009; 23:397-418. [PubMed: 19453201]

24. Jurgens TP, Schaefer C, May A. Treatment of cluster headache in pregnancy and lactation. Cephalalgia. 2009; 29:391-400. [PubMed: 19170693] 
Table 1

FDA medication categories in pregnancy

\begin{tabular}{|c|c|}
\hline Category & Interpretation \\
\hline A & $\begin{array}{l}\text { Adequate, well-controlled studies in pregnant women have not shown an increased risk of fetal abnormalities to the fetus in any } \\
\text { trimester of pregnancy. }\end{array}$ \\
\hline \multirow[t]{3}{*}{ B } & $\begin{array}{l}\text { Animal studies have revealed no evidence of harm to the fetus; however, there are no adequate and well-controlled studies in } \\
\text { pregnant women. }\end{array}$ \\
\hline & OR \\
\hline & $\begin{array}{l}\text { Animal studies have shown an adverse effect, but adequate and well-controlled studies in pregnant women have failed to } \\
\text { demonstrate a risk to the fetus in any trimester. }\end{array}$ \\
\hline \multirow[t]{3}{*}{$\mathrm{C}$} & Animal studies have shown an adverse effect, and there are no adequate and well-controlled studies in pregnant women. \\
\hline & OR \\
\hline & No animal studies have been conducted, and there are no adequate and well-controlled studies in pregnant women. \\
\hline $\mathrm{D}$ & $\begin{array}{l}\text { Adequate well-controlled or observational studies in pregnant women have demonstrated a risk to the fetus. However, the benefits } \\
\text { of therapy may outweigh the potential risk. For example, the drug may be acceptable if needed in a life-threatening situation or } \\
\text { serious disease for which safer drugs cannot be used or are ineffective. }\end{array}$ \\
\hline $\mathrm{X}$ & $\begin{array}{l}\text { Adequate well-controlled or observational studies in animals or pregnant women have demonstrated positive evidence of fetal } \\
\text { abnormalities or risks. The use of the product is contraindicated in women who are or may become pregnant. }\end{array}$ \\
\hline
\end{tabular}

FDA US Food and Drug Administration 
Table 2

Pharmacologic recommendations for treatment of cluster headache in pregnant or lactating women

\begin{tabular}{|c|c|c|c|c|}
\hline & FDA pregnancy category & AAP lactation category & Authors' recommendation & Note \\
\hline \multicolumn{5}{|l|}{ Acute abortive therapy } \\
\hline Oxygen & N/A & N/A & $\begin{array}{l}\text { First line for both pregnancy } \\
\text { and lactation }\end{array}$ & - \\
\hline Sumatriptan (intranasal) & $\mathrm{C}$ & 6: usually compatible & $\begin{array}{l}\text { Second line for both } \\
\text { pregnancy and lactation }\end{array}$ & $\begin{array}{l}\text { If oxygen is not a } \\
\text { choice or } \\
\text { ineffective, } \\
\text { sumatriptan would } \\
\text { be an appropriate } \\
\text { first-line } \\
\text { consideration for } \\
\text { both pregnancy and } \\
\text { lactation. }\end{array}$ \\
\hline Lidocaine (intranasal) & $\mathrm{B}$ & 6: usually compatible & $\begin{array}{l}\text { Second line for both } \\
\text { pregnancy and lactation }\end{array}$ & $\begin{array}{l}\text { If oxygen is not a } \\
\text { choice or } \\
\text { ineffective, } \\
\text { lidocaine would be } \\
\text { an appropriate first- } \\
\text { line consideration } \\
\text { for both pregnancy } \\
\text { and lactation. }\end{array}$ \\
\hline Metoclopramide & $\mathrm{B}$ & 4: may be of concern & $\begin{array}{l}\text { Third line during pregnancy } \\
\text { and lactation }\end{array}$ & $\begin{array}{l}\text { Metoclopramide } \\
\text { has not been proven } \\
\text { effective for } \mathrm{CH} \\
\text { and thus is listed as } \\
\text { third line despite its } \\
\text { relative safety in } \\
\text { pregnancy; safety is } \\
\text { of greater concern } \\
\text { in lactation. }\end{array}$ \\
\hline \multicolumn{5}{|l|}{ Bridge therapy } \\
\hline $\begin{array}{l}\text { GON blockade (using } \\
\text { lidocaine and } \\
\text { betamethasone) }\end{array}$ & $\mathrm{B} / \mathrm{C}$ & 6: usually compatible & $\begin{array}{l}\text { First line for both pregnancy } \\
\text { and lactation }\end{array}$ & $\begin{array}{l}\text { Lidocaine is } \\
\text { Category } \mathrm{B} \text {, and } \\
\text { betamethasone is } \\
\text { Category } \mathrm{C} \text { in } \\
\text { pregnancy. }\end{array}$ \\
\hline Steroids & $\mathrm{C}$ & 6: usually compatible & $\begin{array}{l}\text { Second line for both } \\
\text { pregnancy and lactation }\end{array}$ & - \\
\hline \multicolumn{5}{|l|}{ Preventive therapy } \\
\hline Verapamil & $\mathrm{C}$ & 6: usually compatible & $\begin{array}{l}\text { First line for both pregnancy } \\
\text { lactation }\end{array}$ & - \\
\hline Steroids & $\mathrm{C}$ & 6: usually compatible & $\begin{array}{l}\text { First line for both pregnancy } \\
\text { and lactation }\end{array}$ & - \\
\hline Topiramate & $\mathrm{C}$ & $\begin{array}{l}\text { Has not been reviewed } \\
\text { by the AAP }\end{array}$ & $\begin{array}{l}\text { Second line for pregnancy; } \\
\text { inadequate information to } \\
\text { make recommendation for } \\
\text { lactation }\end{array}$ & $\begin{array}{l}\text { Studies, limited by } \\
\text { open-label design or } \\
\text { small numbers, } \\
\text { suggest topiramate } \\
\text { may be an effective } \\
\text { preventive in CH; } \\
\text { definitive trials are } \\
\text { needed. }\end{array}$ \\
\hline Lithium & $\mathrm{D}$ & 5: caution & $\begin{array}{l}\text { Third line for both pregnancy } \\
\text { and lactation; should be used } \\
\text { only when benefit clearly } \\
\text { exceeds risk }\end{array}$ & - \\
\hline
\end{tabular}

$A A P$ American Academy of Pediatrics, $C H$ cluster headache, FDA US Food and Drug Administration, GON greater occipital nerve 


\section{Table 3}

The American Academy of Pediatrics Committee tables on drugs compatible with breastfeeding ${ }^{a}$

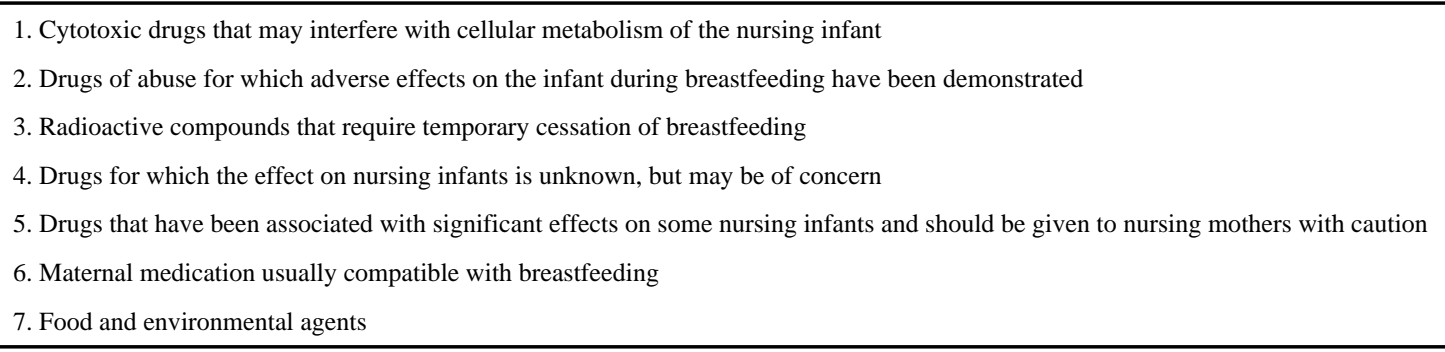

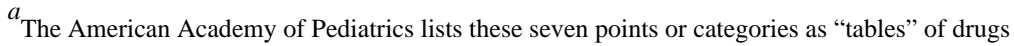

